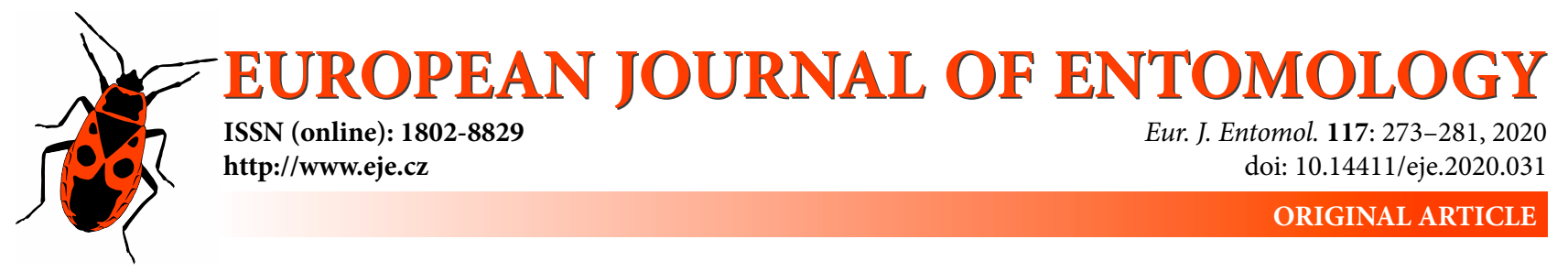

\title{
Diversity of Scarabaeinae (Coleoptera: Scarabaeidae) in an urban fragment of Cerrado in Central Brazil
}

\author{
MARINA R. FRIZZAS ${ }^{1}$, JoÃo L.F.L. BATISTA ${ }^{1}$, MARCus V.C. ROCHA ${ }^{1}$ and ChARLES M. OLIVEIRA $^{2, *}$ \\ ${ }^{1}$ University of Brasília, Department of Zoology, Brasília, DF, 70 910-900, Brazil; e-mails: frizzas@unb.br, joaoflb@hotmail.com, \\ marcus_celani@hotmail.com \\ ${ }^{2}$ Embrapa Cerrados, Planaltina, Brasília, DF, 73 310-970, Brazil; e-mail: charles.oliveira@embrapa.br
}

Key words. Coleoptera, Scarabaeidae, biodiversity, habitat fragmentation, urbanization, Dichotomius carbonarius, Brazil

\begin{abstract}
The diversity of dung beetles (Coleoptera: Scarabaeidae: Scarabaeinae) is affected by urbanization, habitat fragmentation and disappearance of native mammals, which result in changes in the quality and availability of food, and resources for nesting. We evaluated the diversity, distribution of species in different trophic guilds and foraging strategies, and temporal variation in abundance of dung beetles in an urban fragment of Cerrado in a Federal District of Brazil. This study was conducted at the Experimental Station of Biology (EEB) of the University of Brasília (UnB), Federal District, Brazil. Fortnightly, between October 2012 and September 2013, Scarabaeinae were collected using baited (human faeces, pig meat, or banana) and unbaited pitfall traps. Aspects of the dung beetle assemblage were evaluated, including species richness and abundance, feeding habits and foraging strategies. A total of 614 individuals were collected, which included eight species belonging to seven genera and four tribes. Dichotomius carbonarius (Mannerheim, 1829), a generalist species, dominated the assemblage, indicating that it is adapted to living in fragmented and urbanized areas. As regards feeding habits, Eurysternus caribaeus (Jablonsky \& Herbst, 1789) was considered to be strictly coprophagous, Coprophanaeus cyanescens (d'Olsoufieff, 1924) copronecrophagous and $D$. carbonarius a generalist. Most species were classified as paracoprids, which accounted for $75 \%$ of the species collected. Regarding the attractiveness of the bait, the highest numbers of individuals and species were recorded in pitfall traps baited with human faeces. A high abundance of Scarabaeinae was recorded in the first half of the rainy season (October-December) with $98.2 \%$ of the individuals collected in this period. The urban area studied harboured a low number of species with high abundance of a few species.
\end{abstract}

\section{INTRODUCTION}

Habitat fragmentation results in a discontinuity in the spatial distribution of resources, which affects occupation, reproduction and survival of species (Franklin et al., 2002). Several environments around the world have been subjected to fragmentation, including Cerrado, which is the second-largest Brazilian biome. Cerrado has been intensively used by humans because of its geographical position and characteristics, which are favourable for agriculture and raising livestock (Cunha et al., 2008). Another important aspect is that the global human population is growing and becoming increasingly urban. Urban expansion suppresses native vegetation and is a major threat to biodiversity (Groffman et al., 2017) and one of the main factors causing the extinction of species (Macdonald et al., 2008). The growth of urban centres results in marked decreases in insect diversity (Matteson et al., 2008; Magura et al., 2010; Raupp et al., 2010). The main effect of urbanization in reducing insects biodiversity is due to habitat loss, air pollution and artificial light (Muller, 1972).
The differences in the fauna in small urban fragments and conserved environments may be due to the pressures associated with fragmentation and urbanization, including anthropic disturbance, host loss, invasion of new species and climate change (Yahner, 1988; Sánchez-Bayo \& Wyckhuys, 2019). However, although highly modified and disturbed, small urban fragments can still serve as dispersal corridors, or even resting areas for migratory species (Gaston et al., 2005).

In this context, some groups of organisms are considered good biological indicators for monitoring the negative effects of anthropogenic activities that result in environmental disturbance. Scarabaeinae are an ideal group for monitoring biodiversity (Spector, 2006). Many species are sensitive to environmental disturbance, such as habitat fragmentation (Andresen, 2003; Feer \& Hingrat, 2005; Nichols et al., 2007) and urbanization (Radtke et al., 2008; Korasaki et al., 2013), which can result in a decrease in the diversity of species and increase in the dominance of some species (Venugopal et al., 2012). Dung beetle conservation

\footnotetext{
* Corresponding author; e-mail: charles.oliveira@embrapa.br
} 
in urban areas is strongly affected by the paucity of mammals, but dogs and cats (domestic and wild) are present, and dung beetles play an important role in recycling their faeces in urban areas (Carpaneto et al., 2005; Cave, 2005). Because they are associated with mammal faeces, changes in mammalian communities affect the Scarabaeinae community (Culot et al., 2013; Bogoni et al., 2019).

Scarabaeinae are popularly known as dung beetles, of which there is a high diversity of species in the tropics. There are 726 species of dung beetles in Brazil of which 62 are endemic (Vaz-de-Mello, 2018). They are detritivores and use carcasses, decaying fruit and mammalian faeces for feeding and building their nests, with coprophagy the predominant feeding habit of Scarabaeinae (Halffter \& Matthews, 1966; Hanski \& Cambefort, 1991; Barlow et al., 2010; Culot et al., 2013). They perform important ecological roles, such as removing faeces (Horgan, 2005; Kenyon et al., 2016), seed dispersal (Braga et al., 2013), nutrient cycling, bioturbation, plant growth enhancement, parasite suppression and fly control (Nichols et al., 2008). These services are consequences of the nesting and feeding activities of these beetles (Hanski \& Cambefort, 1991). The group is divided into three functional guilds, depending on how they handle a faecal mass (Halffter \& Edmonds, 1982): telecoprids form a faecal ball and roll it away from the source and bury it or leave it on the ground; endocoprids feed in or under fresh faeces, without moving it elsewhere; and paracoprids dig tunnels below or adjacent to faeces in which they bury a faecal mass.

In addition to the nature of the vegetation and characteristics of the relief, climate is one of the main factors determining the abundance of insects (Peacock et al., 2006; Sable \& Rana, 2016). The climate in Cerrado, alternates between dry and rainy seasons (Silva et al., 2008), which determine the behaviour and biology of the insects that inhabit this biome (Silva et al., 2011; Oliveira \& Frizzas, 2013). The climate also directly influences the development of plants and, consequently, the availability of food for several organisms. In the rainy season, the greater availability of food results in an increase in the abundance of animals, including domesticated and wild mammals (Carmignotto et al., 2014; Ferreguetti et al., 2019), which results in an increase in the availability of faeces and carcasses, and the seasonality in the activity of this group of insects.

The aim of this study was to evaluate the diversity, distribution of species in different trophic guilds and foraging strategies, and temporal variation in the abundance of dung beetles in an urban fragment of Cerrado in Brazil.

Our hypothesis is that in Cerrado the greatest diversity (abundance and richness of species) of Scarabaeinae should occur in the rainy season when there is a greater availability of food and the climatic conditions more suitable for the development of insects. In addition, we expect to find a greater diversity of dung beetles associated with human faeces as most Scarabaeinae prefer mammalian faeces.

\section{MATERIAL AND METHODS}

\section{Study area}

This study was carried out at the Experimental Station of Biology (EEB), University of Brasília (UnB), Brasília/DF, Brazil $\left(15^{\circ} 44^{\prime} 13^{\prime \prime} \mathrm{S}, 47^{\circ} 52^{\prime} 57^{\prime \prime} \mathrm{W}\right.$; $1015 \mathrm{~m}$ ) (Fig. 1). The experimental area consisted of $\mathrm{a} \approx 10$-ha fragment of Cerrado. The EEB is an environmental reserve on the shores of Lake Paranoá, with areas for carrying out agricultural and biological research. The soil is predominantly formed by latosols. The fragment studied is composed of cerrado sensu stricto, the biome's main phytophysiognomy, characterized by a low, tortuous and not very dense tree layer. The EEB is close to the Olhos D'Água Park, which is a $\approx 21$-ha ecological and recreational public park. These two areas are the main urban green areas in Northern Brasília. The climate in the region is predominantly tropical, with dry winters (AW) and two well-defined seasons (rainy between October and March and dry between April and September). The altitude ranges from 800 to $1400 \mathrm{~m}$ above mean sea level, the average annual air temperature is between 20 and $22^{\circ} \mathrm{C}$, and precipitation between 1300 and $1600 \mathrm{~mm}$ (Alvares et al., 2013).

\section{Sampling of dung beetles}

Beetles were collected using pitfall traps. The traps consisted of a plastic cylindrical container $9 \mathrm{~cm}$ high and $14 \mathrm{~cm}$ in diameter, to which a second plastic container $(7 \mathrm{~cm}$ high and $8 \mathrm{~cm}$ in diameter) was attached, which is the bait-holder, following the method used by Oliveira \& Mendonça (2011). In the large plastic container, there was $300 \mathrm{ml}$ of water with detergent and copper sulphate $(1 \%)$ to preserve the insects and in the small container, $100 \mathrm{~g}$ of bait. Three types of bait were used: rotting pig meat, decaying bananas and human faeces. A control without bait was also included. Four traps were set at each of four sampling points (Point 1: 1544'11.44"S, 4752'57.79"W, 1014 m; Point 2: $15^{\circ} 44^{\prime} 12.81^{\prime \prime} \mathrm{S}, 47^{\circ} 52^{\prime} 56.71^{\prime \prime} \mathrm{W}, 1014 \mathrm{~m}$; Point 3: $15^{\circ} 44^{\prime} 14.60^{\prime \prime} \mathrm{S}$,

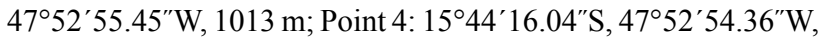
$1014 \mathrm{~m})$, totalling 16 traps. There were four pitfall traps at each sampling point (three baited and a control) arranged in a square, with $50 \mathrm{~m}$ between sampling points and $2 \mathrm{~m}$ between traps, which remained in the field for five days. Collections were made fortnightly from October 2012 to September 2013.

Scarabaeinae were identified to species by F. Zagury Vaz-deMello (Federal University of Mato Grosso, Cuiabá/MT, Brazil). Specimens of the species collected were deposited in the Entomology Collection of the University of Brasília (DZUB) and in the Zoology Collection of the Federal University of Mato Grosso (CEMT). The species were classified according to their foraging strategies (Cambefort \& Hanski, 1991), as paracoprids (tunnellers), telecoprids (rollers), or endocoprids (dwellers).

Climatic data (monthly average air temperature, monthly average relative air humidity and monthly total precipitation) were recorded throughout the experimental period and provided by Embrapa Cerrados (Biophysics Laboratory) (Planaltina/DF, Brazil), located about $20 \mathrm{~km}$ from the experimental area.

\section{Data analysis}

All data analyses were done using R (R Core Team, 2019). The data on abundance and species richness were not normally distributed and did not meet the assumption of homogeneity of variance (Shapiro Wilks test: $\mathrm{W}=0.3166, p<2.2 \mathrm{e}-16$; $\mathrm{W}=0.5318$, $p<2.2 \mathrm{e}-16$; and Bartlett test: $\mathrm{K}=209.3, p<2.2 \mathrm{e}-16$; $\mathrm{K}=57.1$, $p=2.4 \mathrm{e}-12$ ). The Durbin-Watson test (Durbin \& Watson, 1950) revealed that the samples were not spatially $(\mathrm{DW}=2.78, p=$ $0.5352)$ or temporally ( $\mathrm{DW}=2.03, p=0.3813)$ correlated. 


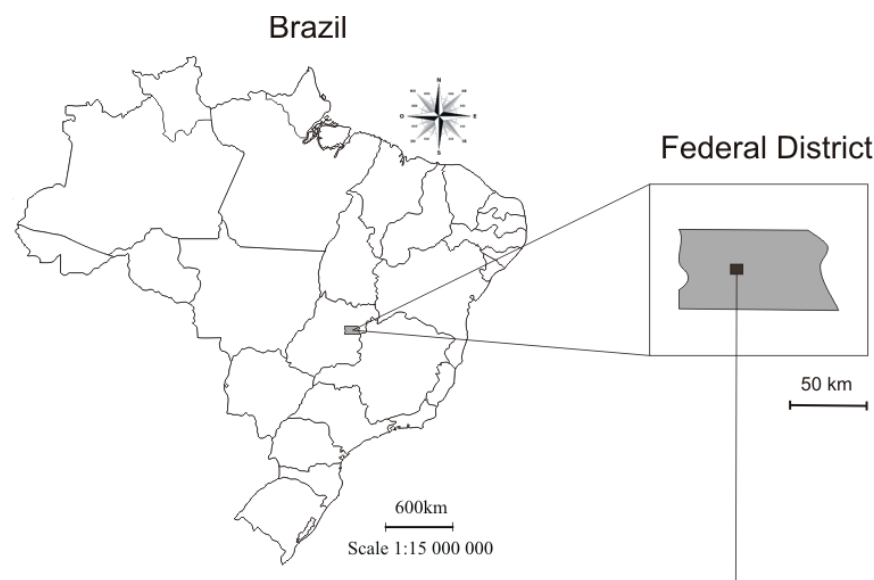

Experimental Station of Biology (EEB) and Olhos D'Água Park (Brasília/DF, Brazil)

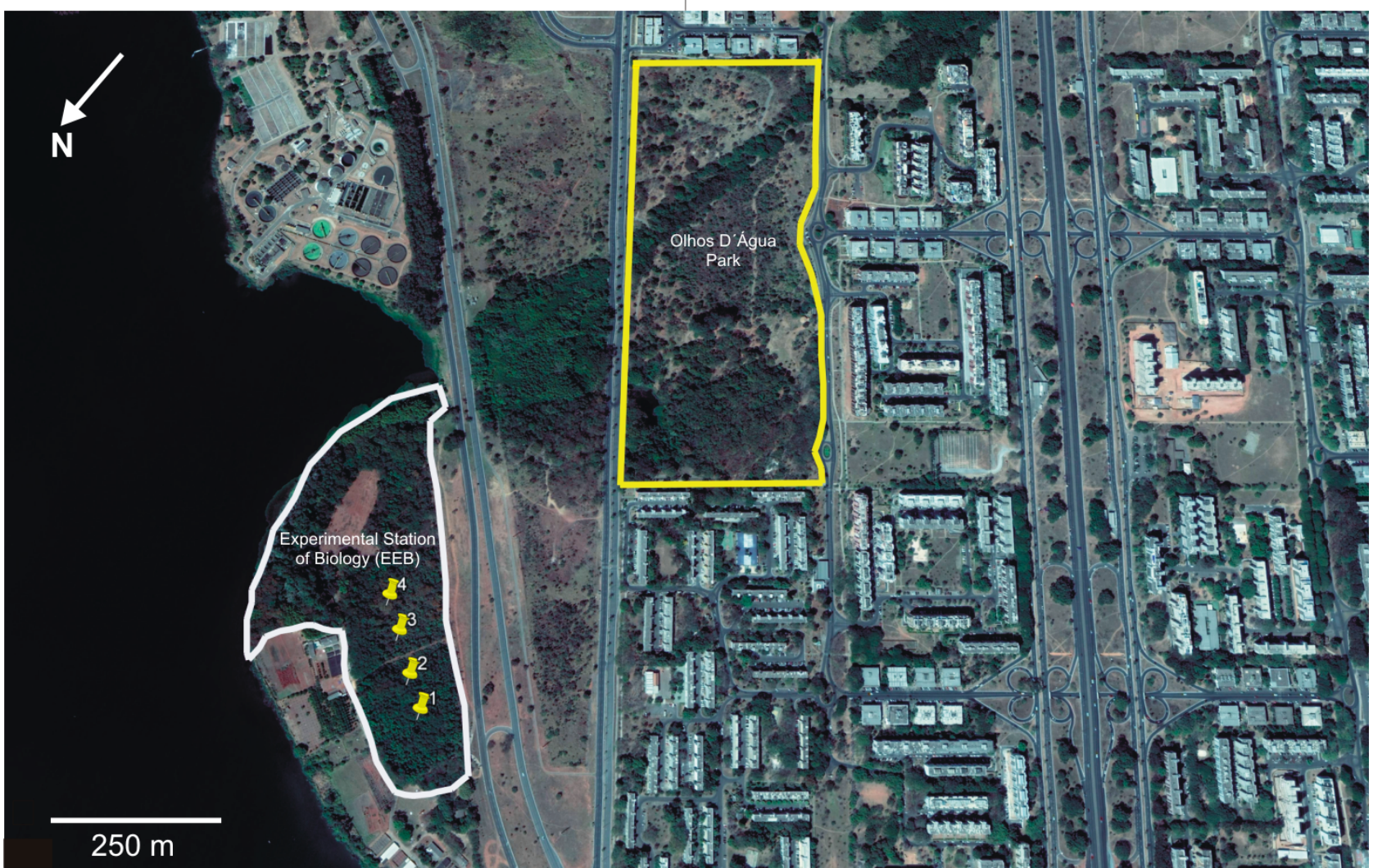

Fig. 1. Aerial photograph of the Experimental Station of Biology (EEB) of the University of Brasilia (UnB), with sites 1 to 4 sampled for Scarabaeinae (for coordinates, see Material and Methods) and the Olhos D’Água Park in Brasília/DF, Brazil indicated.

To evaluate the feeding habits of the different species, we used the Indicator Value (IndVal) analysis to identify the species' preferences for particular baits (Dufrêne \& Legendre, 1997) in the "indicspecies" R package (Caceres et al., 2016). Singletons and doubletons were excluded from this analysis as there were too few individuals for diet inference. Based on their feeding habits the Scarabaeinae were identified as coprophagous (species that the IndVal analysis significantly associated with human faeces), copronecrophagous (species that were significantly associated with human faeces and pig meat), or generalists [species significantly associated with the three types of baits (human faeces, pig meat and banana)].

A generalized linear model (GLM) revealed there was no significant interaction between the response (abundance and species richness) and predictor variables, namely type of bait and month of the year. Thus, it was possible to compare bait attractiveness over the entire period sampled ( $\mathrm{n}=96$ for each bait). In addition, differences in the samples collected in the four periods of the year [first half of the rainy period (Oct-Dec); second half of the rainy period (Jan-Mar); first half of the dry period (Apr-Jun); and second half of the dry period (Jul-Sep)] ( $\mathrm{n}=96$ for each period) were verified. For these comparisons, we used a GLM followed by ANOVA in a logistic regression model using a negative binomial distribution. The GLM selection was previously performed to choose the best model to fit the data using the "hnp" package (Moral et al., 2017). Mean values were statistically separated using Tukey's HSD test at $p<0.05$ in the function "glht" in the "multcomp" package (Hothorn et al., 2016).

Similarly, we used a GLM in a logistic regression model using a negative binomial distribution to verify the influence of climate (monthly average air temperature, monthly average relative air humidity and monthly cumulative total precipitation) on Scara- 


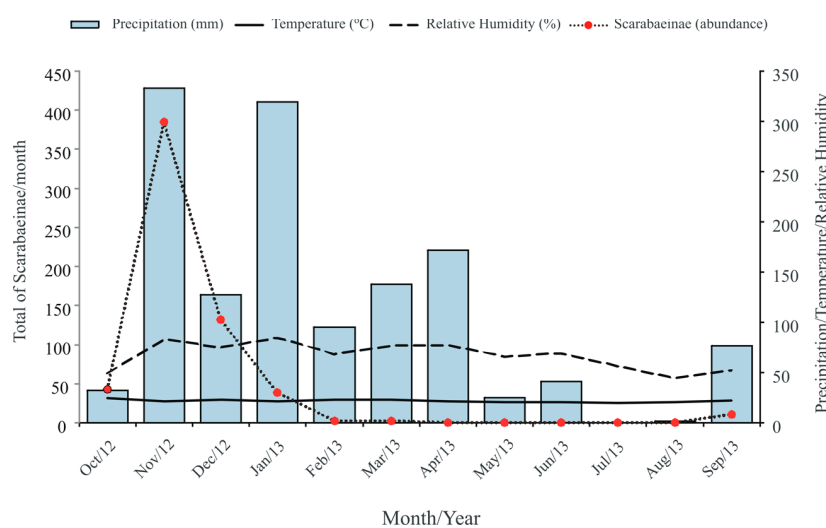

Fig. 2. Average monthly air temperature $\left({ }^{\circ} \mathrm{C}\right)$ and relative air humidity $(\%)$, monthly total precipitation $(\mathrm{mm})$ and abundance of Scarabaeinae caught by baited pitfall traps in a fragmented urban area of Brasília/DF, Brazil between October 2012 and September 2013.

baeinae abundance and richness (monthly abundance and richness - sum of the two sampling events carried out each month).

The number of individuals-based protocol was used and an accumulation curve was constructed in the $\mathrm{R}$ environment, using the "iNEXT" package (Hsieh et al., 2016). In the iNEXT analysis, individual-based abundance data and a diversity order based on species richness $(\mathrm{q}=0)$ were used. iNEXT can interpolate and extrapolate species richness by taking into account a measure of sample coverage (Chao \& Jost, 2012; Chao et al., 2014).

The $\beta$-diversity index expresses the species turnover in terms of a spatial and/or temporal scale. This index was estimated using two formulae. The first measured the intra-site $\beta$-diversity and was calculated using Whittaker's index: $\beta_{\mathrm{w}}=(\mathrm{S} / \alpha)-1$, where $\alpha$ is the average of the $\alpha$-diversity for all the periods sampled (four periods: Oct-Dec; Jan-Mar; Apr-Jun; and Jul-Sep) and S the total number of species recorded in all the periods sampled. The $\beta_{w}$ value varied between 0 and $n-1(n=4)$. The second formula measured the inter-periods, and $\beta$-diversity was calculated using Cody's index: $\beta_{\mathrm{c}}=100 *(\mathrm{Sg}+\mathrm{Sl}) / 2 \alpha$, where $\mathrm{Sg}$ is the difference in the number of species at two sites, $\mathrm{Sl}$ is the number of species lost, and $\alpha$ is the average of the $\alpha$-diversity for the two periods. The Pielou evenness index were calculated using the "BiodiversityR" package (Kindt, 2018).

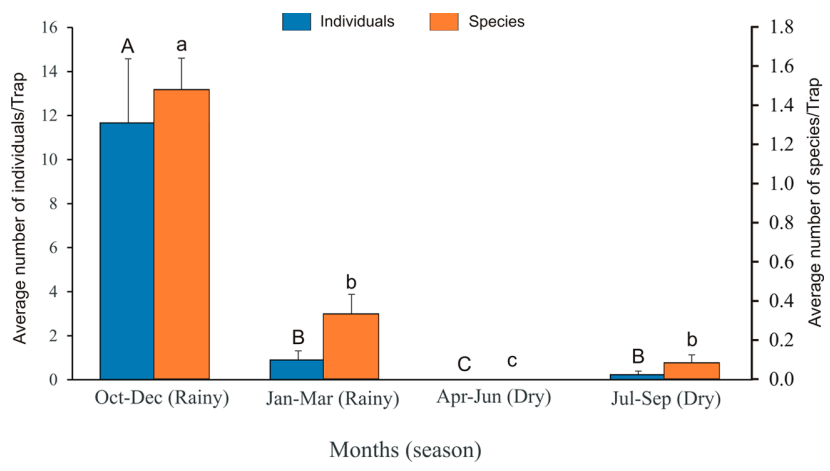

Fig. 3. Average number of individuals/trap and species/trap of Scarabaeinae (Coleoptera: Scarabaeidae), caught in different periods of the year (season), using pitfall traps (baited with human faeces, rotting pig meat, decaying banana or without bait) in a fragmented urban area in Brasília/DF, Brazil between October 2012 and September 2013. Columns with the same capital letter for abundance and lower case for species did not differ statistically according to Tukey's HSD test $(p<0.05)$. Scales above the columns are the standard errors.

\section{RESULTS}

We collected 614 individuals, belonging to eight species, seven genera and four tribes of Scarabaeinae: Ateuchini (one species of Eutrichillum Martínez, 1967), Dichotomiini (two species and one genus, Dichotomius Hope, 1838), Eurysternini (one species of Eurysternus Dalman, 1824), Phanaeini (three species and three genera, Coprophanaeus d'Olsoufieff, 1924, Dendropaemon Perty, 1830 and Diabroctis Gistel, 1857) and "incertae sedis" tribe (one species of Uroxys Westwood, 1842). The most abundant species were Dichotomius carbonarius (Mannerheim, 1829), Eurysternus caribaeus (Jablonsky \& Herbst, 1789) and Eutrichillum hirsutum (Boucomont, 1928), which together accounted for $86.6 \%$ of the total number of individuals caught (Table 1). Dichotomius carbonarius dominated the assemblage, making up $64.3 \%$ of the individuals caught (Table 1).

The IndVal analysis revealed that three species are significantly associated with one or more types of bait. Eu-

Table 1. Number of individuals per species caught by each type of bait and in each period of the year, relative percentage of each species, and trophic and functional guilds of Scarabaeinae beetles caught by pitfall traps in a fragmented urban area in Brasília/DF, Brazil between October 2012 and September 2013.

\begin{tabular}{|c|c|c|c|c|c|c|c|c|c|c|c|}
\hline \multirow{2}{*}{ Species } & \multicolumn{4}{|c|}{ Bait $^{1}$} & \multicolumn{4}{|c|}{$\mathrm{PY}^{2}$} & \multirow{2}{*}{$\%$} & \multirow{2}{*}{$\mathrm{TG}^{3}$} & \multirow{2}{*}{$\mathrm{FG}^{4}$} \\
\hline & $\mathrm{HF}$ & RPM & $\mathrm{DB}$ & WB & $\mathrm{J}-\mathrm{M}$ & A-J & $\mathrm{J}-\mathrm{S}$ & O-D & & & \\
\hline Dichotomius carbonarius & 179 & 103 & 108 & 5 & 33 & 0 & 0 & 360 & 64.3 & G & $\mathrm{P}$ \\
\hline Eurysternus caribaeus & 69 & 1 & 0 & 0 & 0 & 0 & 9 & 61 & 11.4 & $\mathrm{C}$ & $E$ \\
\hline Eutrichillum hirsutum & 23 & 34 & 10 & 0 & 2 & 0 & 0 & 65 & 10.9 & - & $E$ \\
\hline Dichotomius bicuspis & 4 & 13 & 17 & 7 & 6 & 0 & 2 & 35 & 6.7 & - & $\mathrm{P}$ \\
\hline Coprophanaeus cyanescens & 16 & 21 & 1 & 0 & 1 & 0 & 0 & 37 & 6.2 & $\mathrm{CN}$ & $\mathrm{P}$ \\
\hline Diabroctis mimas & 1 & 0 & 0 & 0 & 0 & 0 & 0 & 1 & 0.2 & - & $P$ \\
\hline Dendropaemon flechtmanni & 0 & 0 & 1 & 0 & 1 & 0 & 0 & 0 & 0.2 & - & $\mathrm{P}$ \\
\hline Uroxys sp. & 1 & 0 & 0 & 0 & 0 & 0 & 0 & 1 & 0.2 & - & $\mathrm{P}$ \\
\hline Number of species & 7 & 5 & 5 & 2 & 5 & 0 & 2 & 7 & & & \\
\hline Number of individuals & 293 & 172 & 137 & 12 & 43 & 0 & 11 & 560 & & & \\
\hline
\end{tabular}

${ }^{1} \mathrm{HF}$ - human faeces, RPM - rotting pig meat, DB - decaying banana, WB - without bait; ${ }^{2}$ Period of the year: J-M: January-March, A-J: April-June, J-S: July-September, O-D: October-December. ${ }^{3}$ TG - trophic guild [classification based on Value Indicator (IndVal)] (see Material and Methods): G - generalist, C - coprophagous, CN - copronecrophagous and "-" not significantly associated with any bait; ${ }^{4} \mathrm{FG}$ - functional guild: $\mathrm{P}$ - paracoprid, and $\mathrm{E}$ - endocoprid. 


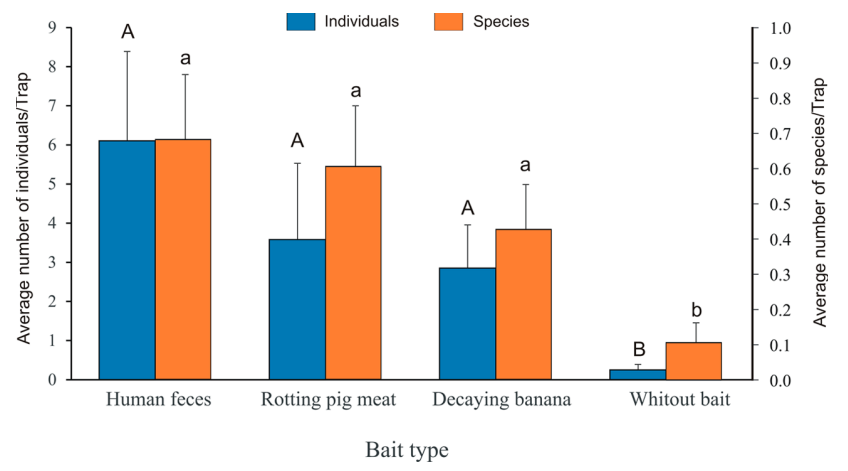

Fig. 4. Average number of individuals/trap and species/trap of Scarabaeinae (Coleoptera: Scarabaeidae) collected using pitfall traps (baited with human faeces, rotting pig meat, decaying banana or without bait) in a fragmented urban area in Brasilia/DF, Brazil between October 2012 and September 2013. Columns with the same capital letter for abundance and lower case for species did not differ statistically according to Tukey's HSD test $(p<0.05)$ Scales above the columns are the standard errors.

rysternus caribaeus was significantly associated only with human faeces (stat $=0.351 ; p=0.002$ ), indicating that it is a strictly coprophagous species. Coprophanaeus cyanescens (d'Olsoufieff, 1924) was associated with faeces and pig meat (stat $=0.318 ; p=0.02$ ), and is a copronecrophagous species, and $D$. carbonarius was significantly associated with all baits (faeces, pig meat and banana) (stat = $0.49 ; p=0.006$ ) and was considered to be a generalist. In terms of functional guild, two species were classified as endocoprids ( $25 \%$ of species) and six were classified as paracoprids ( $75 \%$ of species) (Table 1$)$.

All of the species of Scarabaeinae and $98.2 \%$ of the individuals were caught from October to March, which is the rainy season in Cerrado, and the maximum number of individuals $(62.7 \%)$ were caught in November (Fig. 2). In the first half of the rainy season (October-December), the number of Scarabaeinae and species caught was significantly higher than in the other seasons sampled (Individuals: Oct/Dec-Apr/Jun: $\mathrm{z}=9.136, p<0.001$; Oct/DecJul/Sep: $\mathrm{z}=7.182, p<0.001$, and Oct/Dec-Jan/Mar: $\mathrm{z}=$ 5.331, $p<0.001$; Species: Oct/Dec-Apr/Jun: $\mathrm{z}=7.789, p$ $<0.001$; Oct/Dec-Jul/Sep: $\mathrm{z}=5.393, p<0.001$, and Oct/ Dec-Jan/Mar: $\mathrm{z}=4.786, p<0.001)$ and the lowest number of individuals and species caught was in the first half of the dry season (Fig. 3).

In terms of bait attractiveness, the highest numbers of individuals $(47.7 \%)$ and species $(87.5 \%)$ were caught using human faeces (Table 1) and the lowest numbers of individuals (22.3\%) and species (62.5\%) were caught using banana bait. Although the number of individuals and species of Scarabaeinae caught using human faeces, pig meat and banana was significantly higher than that caught by unbaited traps (Individuals: without bait-banana: $\mathrm{z}=-3.228, p=$ 0.0069; without bait-pig meat: $\mathrm{z}=-3.527, p=0.0023$ and without bait-human faeces: $\mathrm{z}=-4.246, p<0.001$; Species: without bait-banana: $\mathrm{z}=-2.556, p=0.0375$; without baitpig meat: $\mathrm{z}=-2.807, p=0.0245$, and without bait-human faeces: $\mathrm{z}=-3.058, p<0.011)$, there were no statistical differences between the bait types (Fig. 4).

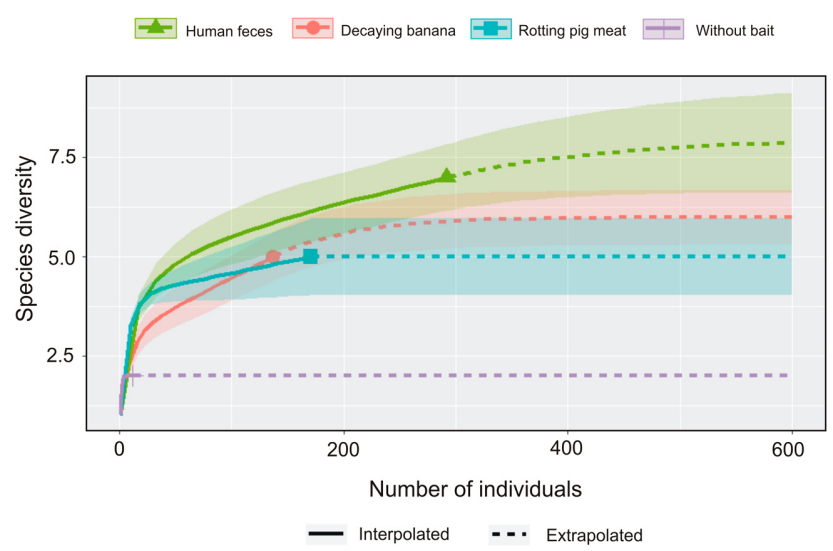

Fig. 5. Sample size-based rarefaction and extrapolation using a Hill numbers sampling curve (species richness estimates for a rarefied and extrapolated sample with sample size up to double the reference sample size) for Scarabaeinae (Coleoptera: Scarabaeidae) caught using pitfall traps baited with human faeces, rotting pig meat, decaying banana or without bait, in a fragmented urban area in Brasília/DF, Brazil between October 2012 and September 2013. Areas below and above the curves are the standard deviations.

Abundance and richness of the Scarabaeinae was significantly influenced by precipitation (abundance: $\mathrm{z}=4.382$, $p<0.001$; richness: $\mathrm{z}=5.165, p<0.001)$ and temperature (abundance: $\mathrm{z}=4.791, p<0.001$; richness: $\mathrm{z}=4.221, p$ $<0.001)$. Relative humidity did not significantly influence these variables (abundance: $\mathrm{z}=0.343, p=0.731$; richness: $\mathrm{z}=-1.459, p=0.144)$.

The results of iNEXT indicate that the sample coverage for the evaluation of species richness was satisfactory, and this was $98.6 \%$ for banana, $99.3 \%$ for human faeces and $100 \%$ for pig meat and traps without bait. Diversity estimates based on rarefied and extrapolated samples for traps without bait were two species, and ranged from 5.9 to 8.0 species for faeces, from 4.0 to 5.9 species for pig meat and from 4.2 to 5.7 for banana. Sample size-based rarefaction and extrapolation sampling curves showed that the curves for pig meat and traps without bait reached an asymptote, indicating that the number of samples provided adequate coverage of the study area. For human faeces and banana baits, however, an increase in sampling effort might have revealed a higher species richness (Fig. 5).

The $\beta_{\mathrm{w}}$-diversity index for the area studied was 1.29. The $\beta_{\mathrm{c}}$-diversity index, which measures the variation in the composition of species in the different periods of the year, was 100\% between Jan-Mar and Apr-Jun and between Apr-Jun and Jul-Sep, and 55.6\% between Jul-Sep and Oct-Dec. For the Scarabaeinae community the Pielou evenness index was 0.56 .

\section{DISCUSSION}

The importance of the Scarabaeinae as ecosystem service providers is recognized, because they remove faeces and disperse seed (Nichols et al., 2008; Braga et al., 2013; Kenyon et al., 2016) and are important biological indicators of anthropogenic activities that disturb the environment (Spector, 2006; Nichols et al., 2007; Korasaki et al., 2013). However, more attention should be given to the ef- 
fects on these organisms of habitat fragmentation generated by urbanization and how they can be used as biological indicators in the conservation of urban ecological reserves. A recent review of 27 articles related to this topic in 17 countries revealed that $40 \%$ of them were for the American continent (Ramírez-Restrepo \& Halffter, 2016).

Our results are similar to those reported for other urban parks, with a low number of species $(n=8)$ and a high abundance of a few species. The Pielou evenness index $(0.56)$ indicates a low uniformity in the distribution of abundance among the species. In an urban park in Rome, the number of dung beetle species decreased from 19 to 9 in 13 years (Carpaneto et al., 2005). In the Olhos D’Água Park near the experimental area (Federal District, Brazil), seven species of Scarabaeinae were previously recorded (Nunes \& Frizzas, 2007). However, we should take into account that only one area was sampled in this study and that this urban area might be shown to contain more species if additional areas were sampled. In contrast, studies of large conserved areas of Cerrado report a high number of species of Scarabaeinae, with a more uniform distribution. For example, in this Federal District, 38 species of Scarabaeinae were found in a cerrado sensu stricto area (Rocha, 2016), 27 species in a rupestrian field (Nunes et al., 2012), and 102 species in "campo sujo [bushy grassland]", cerrado sensu stricto and gallery forest areas (Milhomem et al., 2003). In Mato Grosso State, Brazil, 44 species are recorded in Chapada dos Guimarães (Daniel et al., 2014) and 29 species in Chapada dos Parecis (Silva et al., 2010). Species, genus and tribe composition of Scarabaeinae can also differ widely between extensive and conserved areas of Cerrado natural vegetation and isolated fragments, such as the one studied here. In a Scarabaeinae survey conducted in a conservation area (Parque Nacional de Brasília - PNB), only 4 km from our experimental area, Rocha (2016) records the presence of two tribes (Deltochilini and Onthophagini) and 14 genera that were not collected by us. The two most abundant species in PNB were two Phanaeini [Oxysternon palemo Castelnau, 1840 and Coprophanaeus spitzi (Pessôa, 1934)] (Rocha, 2016) and in our study the most abundant species were one Dichotomiini (D. carbonarius) and one Ateuchini (E. hirsutum).

This indicates that the reduction in areas of native vegetation and the formation of isolated fragments of vegetation (such as the area studied) result in a marked reduction in the diversity and changes in the composition of Scarabaeinae. This is likely to be associated with a decline in food resources (e.g. mammals' faeces, carcasses or decomposing plant material) and a reduction in the diversity of habitats that provide better competitive conditions for species adapted to the specific characteristics of fragments of the remaining vegetation (Driscoll \& Weir, 2005; Puker et al., 2014).

The distribution of dung beetles in space and time varies depending on biotic and abiotic factors, such as climate (Lumaret \& Kirk, 1987; Korasaki et al., 2013) and availability of resources (Doube, 1987; Sanchez-Piñero, 1997). Rainfall and temperature had significant effects on the abundance and species richness of Scarabaeinae. Dung beetles are most abundant in the rainy season, when both precipitation and temperature are high (Martínez \& Vásquez, 1995; Damborsky et al., 2015). In Cerrado, the high availability of food, such as leaves, flowers, and fruit (Morais \& Diniz, 2004; Oliveira, 2008) in this season, is associated with an increase in the activity and abundance of most of the animals that inhabit this biome (Malheiros, 2016). Increase in resources, such as fruit, carcasses and faeces in this season favour Scarabaeinae. In contrast, in a reserve in Argentina, the highest values of species richness and abundance of Scarabaeinae are reported in months when the temperature is high and rainfall low (Ibarra-Polesel et al., 2015).

The temporal turnover of species recorded between periods $\left(\beta_{\mathrm{c}}\right.$-diversity), indicate changes in species composition of between 55.6 and $100 \%$ in the two periods in a year and that species alternate in their relative importance throughout a year by using the resources in each period differently. For example, D. carbonarius was the main species in the rainy season and E. caribaeus in the dry season (Table 1). The Scarabaeinae assemblage seems to be structured around one or two species that dominate this habitat in the different seasons of a year.

Dichotomius carbonarius, a generalist species, dominated the dung beetle assemblage $(64.3 \%$ of the individuals caught), which indicates that it is adapted to fragmented and urbanized areas. Similarly, it is one of the most abundant species in a fragment of urban cerrado in Goiás State, Brazil (Borges Júnior et al., 2011). This species has evolved a novel adaptive strategy of constructing chambers using crushed leaves rather than faeces (Dinghi et al., 2013), and despite being found in forested areas, seems to be able to colonize agricultural environments and other open areas (Durães et al., 2005; Almeida \& Louzada, 2009), indicating great plasticity in its ability to survive in different environments. A reduction in specialist species and increase in generalist species is usually associated with urbanization (Magura et al., 2004; Elek \& Lövei, 2007) along with taxonomic homogenization, with only a few locally abundant species, is an important negative consequence of urbanization (Magura et al., 2010).

Interestingly, a species of the genus Dendropaemon was caught using pitfall traps baited with decaying banana. Species of this genus are commonly caught by flight intercept or light traps (Vaz-de-Mello \& Génier, 2009), which leads us to believe that the collection of $D$. flechtmanni Génier \& Arnaud, 2016 was accidental.

In addition to mammalian faeces, other types of resource, such as rotting meat or decaying fruit, can be used by species of Scarabaeinae. The great abundance and species richness recorded in studies that use human faeces to catch dung beetles may be because the Scarabaeinae include a large number of coprophagous species (Halffter \& Matthews, 1966; Hanski \& Cambefort, 1991; Gardner et al., 2008). However, in the present study, no significant difference was recorded between the types of bait used, possibly because the mammal community has been drastically 
reduced in fragmented areas in urban environments (Gibson et al., 2013), which favours species of Scarabaeinae that are able to use scarce resources, such as mushrooms or decaying fruit (Hanski \& Cambefort, 1991).

Six species (75\% of species) were classified as paracoprids. Similar results are reported for fragmented and degraded areas in Colombia (Martínez et al., 2009; Barraza et al., 2010). A high percentage of paracoprid species indicate a scarcity of food and rapid desiccation faeces, which favours species that quickly bury faeces, which reduces competition and increases reproductive success. In contrast, the resource requirements of endocoprid species is usually high (Halffter \& Edmonds, 1982), but they are scarce in fragmented and urbanized areas. Dung beetles of different functional guilds respond to changes in the structure of vegetation in different ways. Open habitats, such as urban parks, can directly increase the rate of desiccation of faeces, which restricts telecoprids and endocoprids to more shaded areas (Hanski \& Cambefort, 1991). In contrast, in southern Europe the composition and structure of dung beetle assemblages are affected by the extent of the cover of vegetation, which when dense results in a low abundance and species richness and a drastic reduction dung beetle biodiversity (Errouissi \& Jay-Robert, 2019).

In urban green areas, dog and cat faeces are a hygiene problem, because they may contain fungi (Penicillium and Aspergillus) and bacteria (Staphylococcus and Salmonella) of medical importance (Nunes \& Frizzas, 2007). However, dog and cat faeces are abundant and used by a larger number of species of Scarabaeinae than the faeces of wild carnivores (Carpaneto et al., 2005). In urban areas, dogs and cats are omnivorous feeding on human food debris with high cellulose and carbohydrate contents, and dung beetles normally avoid the faeces of strict carnivores due to their low cellulose content (Landin, 1961). We did not record mammal diversity, however, there are small- and mediumsized mammals in the area studied, particularly possums, domestic dogs and cats, which could provide food for the dung beetles present in the area (J.S. Marinho Filho, University of Brasília, pers. com.).

It is widely expected that habitat destruction in the tropics will result in the extinction of many species in coming years, but while the potential magnitude of the loss is unclear, it is likely the increased level of disturbance will have a marked effect on the global diversity of individual groups, such as dung beetles (Alroy, 2017). Our results indicate that small fragments of Cerrado in an urban environment support a lower diversity and different species composition of Scarabaeinae than extensive and conserved areas (Nunes et al., 2012; Daniel et al., 2014; Rocha, 2016). These areas are the habitat of species of Scarabaeinae that are able to use scarce resources, which vary in space and time, but are most abundant in the rainy season. However, because of the ecological importance of dung beetles, urban parks should be conserved and expanded, because they serve as important refuges for some of the species in this group of organisms. In addition, it is essential to study urban environments to support public planning and conservation policies, and understanding urban biodiversity is one of the key to the success of conservation efforts (Soanes et al., 2019; Wintle et al., 2019).

ACKNOWLEDGEMENTS. We thank F. Zagury Vaz-de-Mello for identifying the species and the Scientific Initiation Program of the University of Brasília (ProIC/DPP/UnB) and the National Council of Scientific and Technological Development (CNPq) for providing a scholarship for the second author. MRF and CMO have CNPq (National Council for Scientific and Technological Development) fellowships (313952/2018-3 and 312050/2017-8).

\section{REFERENCES}

AlmEIDA S.S.P. \& LouZADA J.N.C. 2009: Estrutura da comunidade de Scarabaeinae (Scarabaeidae: Coleoptera) em fitofisionomias do cerrado e sua importância para a conservação. — Neotrop. Entomol. 38: 32-43.

Alroy J. 2017: Effects of habitat disturbance on tropical forest biodiversity. - Proc. Natn. Acad. Sci. 114: 6056-6061.

Alvares C.A., Stape J.L., Sentelhas P.C., Moraes G., Leonardo J. \& Sparovek G. 2013: Köppen's climate classification map for Brazil. - Meteorol. Z. 22: 711-728.

ANDRESEN E. 2003: Effect of forest fragmentation on dung beetle communities and functional consequences for plant regeneration. - Ecography 26: 87-97.

Barlow J., Louzada J., Parry L., Hernández M.I.M., Hawes J., Peres C.A., Vaz-de-Mello F.Z. \& Gardner T.A. 2010: Improving the design and management of forest strips in human dominated tropical landscapes: a field test on Amazonian dung beetles. - J. Appl. Ecol. 47: 779-788.

Barraza J., Montes J., Martínez N. \& Deloya C. 2010: Ensambalje de escarabajos coprófagos (Scarabaeidae: Scarabaeinae) del bosque tropical seco Bahia Concha, Santa Marta, Colombia. - Rev. Colomb. Entomol. 36: 285-291.

Bogoni J.A., Silva P.G. \& Peres C.A. 2019: Co-declining mamma-dung beetle faunas throughout the Atlantic Forest biome of South America. - Ecography 42: 1803-1818.

Borges Júnior N.F., Machado G.A. \& Battirola L.D. 2011: Scarabaeidae (Coleoptera) coprófagos em fragmentos de vegetação nativa (Cerrado) no perímetro urbano de Catalão, Goiás (Brasil). - Acta Biol. Paranaen. 40: 73-85.

Braga R.F., Korasaki V., Andresen E. \& Louzada J. 2013: Dung beetle community and functions along a habitat-disturbance gradiente in the Amazon: a rapid assessment of ecological functions associated to biodiversity. - PLOS ONE 8(2): e57786, $12 \mathrm{pp}$.

Caceres M., Jansen F. \& De Caceres M.M. 2016: Package 'Indicspecies'. Relationship Between Species and Groups of Sites. R package version, 1(6). URL: ftp://r-project.org/pub/R/web/ packages/indicspecies/indicspecies.pdf

CAmbefort Y. \& Hanski I. 1991: Dung beetle population biology. In Hanski I. \& Cambefort Y. (eds): Dung Beetle Ecology. Princeton University Press, Princeton, NJ, pp. 36-50.

Carmignotto A.P., Bezerra A.M. \& Rodrigues F.H. 2014: Nonvolant small mammals from a southwestern area of Brazilian Cerrado: diversity, habitat use, seasonality, and biogeography. - Therya 5: 535-558.

Carpaneto G.M., Mazziotta A. \& Piattella E. 2005: Changes in food resources and conservation of scarab beetles: from sheep to dog dung in a green urban area of Rome (Coleoptera, Scarabaeoidea). - Biol. Conserv. 123: 547-556.

CAVE R.D. 2005: Observations of urban dung beetles utilizing dog feces (Coleoptera: Scarabaeidae). - Coleopts. Bull. 59: 400-401. 
Chaо A. \& Jost L. 2012: Coverage-based rarefaction and extrapolation: standardizing samples by completeness rather than size. - Ecology. 93: 2533-2547.

Chao A., Gotelli N.J., Hsieh T.C., Sander E.L., Ma K.H., ColWELL R.K. \& ELLISON A.M. 2014: Rarefaction and extrapolation with Hill numbers: a framework for sampling and estimation in species diversity studies. - Ecol. Monogr. 84: 45-67.

Culot L., Bovi E., Vaz-de-Mello F.Z., Guevara R. \& Galetti M. 2013: Selective defaunation affects dung beetle communities in continuous Atlantic rainforest. - Biol. Conserv. 163: $79-89$.

Cunha N.R.S., Lima J.E., Gomes M.F.M. \& Braga M.J. 2008: A intensidade da exploração agropecuária como indicador da degradação ambiental na região dos Cerrados, Brasil. — Revta Econ. Sociol. Rural 46: 291-323.

Damborsky M.P., Alvarez-Bohle M.C., Ibarra-Polesel M.G., Porcel E.A. \& Fontana J.L. 2015: Spatial and temporal variation of dung beetle assemblages in a fragmented landscape at Eastern Humid Chaco. — Neotrop. Entomol. 44: 30-39.

Daniel G.M., Nunes L.G.O.A. \& VaZ-De-Mello F.Z. 2014: Species composition and functional guilds of dung beetle (Insecta: Coleoptera: Scarabaeidae: Scarabaeinae) in different vegetational types in the Brazilian Shield-Chacoan Depression Border. - Ann. Soc. Entomol. Fr. (N.S.) 50: 183-190.

Dinghi P.A., SÁnchez M.V., Cantil L.F., Sarzetti L.C. \& Genise J.F. 2013: Leaf-litter brood chambers in Dichotomius (Luederwaldtinia) carbonarius (Mannerheim, 1829) (Coleoptera: Scarabaeidae): a novel behavior for dung beetles. - Coleopts. Bull. 67: 388-396.

Doube B.M. 1987: Spatial and temporal organization in communities associated with dung pads and carcasses. In Gee J.H.R. \& Giller P.S. (eds): Organization of Communities: Past and Present. Blackwell Scientific Publications, Oxford, pp. 255-280.

Driscoll D.A. \& WeIR T. 2005: Beetle responses to habitat fragmentation depend on ecological traits, habitat condition, and remnant size. - Conserv. Biol. 19: 182-194.

DufrêNE M. \& LEGENDRE P. 1997: Species assemblages and indicator species: the need for a flexible asymmetrical approach. - Ecol. Monogr. 67: 345-366.

Durães R., Martins W. \& VaZ-De-Mello F.Z. 2005: Dung beetle (Coleoptera: Scarabaeidae) assemblages across a natural forest-Cerrado ecotone in Minas Gerais, Brazil. - Neotrop. Entomol. 34: 721-731.

Durbin J. \& WATSON G.S. 1950: Testing for serial correlation in least squares regression. 1. - Biometrika 37: 409-428.

EleK Z. \& LÖVEI G. 2007: Patterns in ground beetle (Coleoptera: Carabidae) assemblages along an urbanization gradient in Denmark. - Acta Oecol. 32: 104-111.

Errouissi F. \& JAY-Robert P. 2019: Consequences of habitat change in euromediterranean landscapes on the composition and diversity of dung beetle assemblages (Coleoptera, Scarabaeoidea). - J. Insect Conserv. 23: 15-28.

Feer F. \& Hingrat Y. 2005: Effects of forest fragmentation on a dung beetle community in French Guiana. - Conserv. Biol. 19: $1103-1112$.

Ferreguetti A.C., Lessa I.C.M., Vieira E.M., Cunha A.A. \& Bergallo H.G. 2019: Medium- and large-sized mammal composition in the Chapada dos Veadeiros National Park and adjacent areas, state of Goiás, Brazil. - Pap. Avulsos Zool. 59: e20195942, 7 pp.

Franklin A.B., Noon B.R. \& George T.L. 2002: What is habitat fragmentation? - Stud. Avian Biol. 25: 20-29.

Gardner T.A., Hernández M.I.M., Barlow J. \& Peres C.A. 2008: Understanding the biodiversity consequences of habitat change: the value of secondary and plantation forests for neotropical dung beetles. - J. Appl. Ecol. 45: 883-893.

Gaston K.J., Warren P.H., Thompson K. \& Smith R.M. 2005: Urban domestic gardens (IV): the extent of the resource and its associated features. - Biodiv. Conserv. 14: 3327-3349.

Gibson L., Lynam A.J., Bradshaw C.J.A., He F., Bickford D.P., Woodruff D.S., BumrungsR S. \& LaURANCE W.F. 2013: Nearcomplete extinction of native small mammal fauna 25 years after forest fragmentation. - Science 341: 1508-1510.

Groffman P.M., Cadenasso M.L., Cavender-Bares J., Childers D.L., Grimm N.B., Grove J.M., Hobbie S.E., Hutyra L.R., Jenerette G.D., McPhearson T., Pataki D.E., Pickett S.T.A., Pouyat R.V., Rosi-Marshall E. \& Ruddell B.L. 2017: Moving towards a new urban systems science. - Ecosystems 20: $38-43$.

Halffter G. \& Edmonds W.D. 1982: The Nesting Behavior of Dung Beetles (Scarabaeinae): An Ecological and Evolutive Approach. Instituto de Ecologia, Mexico, 177 pp.

Halffter G. \& Matthews E.G. 1966: The natural history of dung beetles of the subfamily Scarabaeinae (Coleoptera: Scarabaeidae). - Folia Entomol. Mex. 12/14: 1-312.

Hanski I. \& CAmbefort Y. 1991: Dung Beetle Ecology. Princeton University Press, New Jersey, 520 pp.

HoRGAN F.G. 2005: Effects of deforestation on diversity, biomass and function of dung beetles on the eastern slopes of the Peruvian Andes. - Forest Ecol. Manag. 216: 117-133.

Hothorn T., Bretz F., Westfall P., Heiberger R.M., SchuetzenMeister A., Scheibe S. \& Hothorn M.T. 2016: Package 'multcomp'. Simultaneous Inference in General Parametric Models. Project for Statistical Computing, Vienna. URL: https://cran.rproject.org/web/packages/multcomp/

Hsien T.C., MA K.H. \& CHAO A. 2016: iNEXT: an R package for rarefaction and extrapolation of species diversity (Hill numbers). - Methods Ecol. Evol. 7: 1451-1456.

Ibarra-Polesel M.G., Damborsky M.P. \& Porcel E. 2015: Escarabajos copronecrófagos (Scarabaeidae: Scarabaeinae) de la Reserva Natural Educativa Colonia Benítez, Chaco, Argentina. - Rev. Mex. Biodiv. 86: 744-753.

Kenyon T.M., Mayfield M.M., Montheith G.B. \& Menéndez R. 2016: The effects of land use change on native dung beetle diversity and function in Australia's Wet Tropics. - Austral. Ecol. 41: 797-808.

KINDT R. 2018: Package "BiodiversityR". Package for Community Ecology and Suitability Analysis. Ver. 1.10-1. The comprehensive R archive network. URL: https://cran.r-project.org/ web/packages/BiodiversityR/index.html

Korasaki V., Lopes J., Brown G.G. \& Louzada J. 2013: Using dung beetles to evaluate the effects of urbanization on Atlantic Forest biodiversity. - Insect Sci. 20: 393-406.

LANDIN B.O. 1961: Ecological studies on dung beetles (Col.: Scarabaeidae). - Opusc. Entomol. 19: 1-277.

LumARET J.P. \& KirK A.A. 1987: Ecology of dung beetles in the French Mediterranean region (Coleoptera, Scarabaeidae). Acta Zool. Mex. 24: 1-60.

Magura T., Tóthmérész B. \& Molnár T. 2004: Changes in carabid assemblages along an urbanization gradient in the city of Debrecen, Hungary. — Landsc. Ecol. 19: 747-759.

Magura T., Lövei G.L. \& Tóthmérész B. 2010: Does urbanization decrease diversity in ground beetle (Carabidae) assemblages? - Global Ecol. Biogeogr. 19: 16-26.

Malheiros R. 2016: A influência da sazonalidade na dinâmica da vida no bioma Cerrado. - Rev. Bras. Climatol. 19: 113-128.

MARTínez I.M. \& VÁsquez A.A. 1995: Influencia de algunos factores ambientales sobre la reproducion em Canthon cyanellus 
cyanellus Le Cont (Coleoptera: Scarabaeidae: Scarabeinae). Elytron 9: 5-13.

Martínez N.J., García H., Pulido L.A., Ospino D.D. \& Narváez J.C. 2009: Escarabajos coprófagos (Coleoptera: Scarabaeinae) de la vertiente noroccidental, Sierra Nevada de Santa Marta, Colombia. - Neotrop. Entomol. 38: 708-715.

Matteson K.C., Asherand J.S. \& Langellotto G.A. 2008: Bee richness and abundance in New York city urban gardens. Ann. Entomol. Soc. Am. 101: 140-150.

McDonald R.I., Kareiva P. \& Forman R.T.T. 2008: The implications of current and future urbanization for global protected areas and biodiversity conservation. - Biol. Conserv. 141: $1695-1703$.

Milhomem M.S., Vaz-De-Mello F.Z. \& Diniz I.R. 2003: Técnicas de coleta de besouros copronecrófagos no Cerrado. - Pesq. Agropec. Bras. 38: 1249-1256.

Morais H.C. \& Diniz I.R. 2004: Herbívoros e herbivoria no Cerrado: lagartas como exemplo. In Aguiar L.M.S. \& Camargo A.J.A. (eds): Cerrado: Ecologia e Caracterização. Embrapa Cerrados, Embrapa Informação Tecnológica, Brasília, pp. 159-176.

Moral R.A., Hinde J. \& Demétrio C.G.B. 2017: Half-normal plots and overdispersed models in R: The hnp Package. $-J$. Stat. Softw. 81: 10, 23 pp.

Muller J. 1972: Is air pollution responsible for melanism in Lepidoptera and for scarcity for all orders of insects in New Jersey? - J. Res. Lepidopt. 10: 89-90.

Nichols E., Larsen T., Spector S., Davis A.L., Escobar F., Favila M. \& VULINEC K. 2007: Global dung beetle response to tropical forest modification and fragmentation: a quantitative literature review and meta-analysis. - Biol. Conserv. 137: 1-19.

Nichols E., Spector S., Louzada J., Larsen T., Amezquita S. \& FAVILA M.E. 2008: Ecological functions and ecosystem services provided by Scarabaeinae dung beetles. - Biol. Conserv. 141: $1461-1474$.

Nunes R.V. \& FrizzAs M.R. 2007: Microbiota da flora intestinal de besouros (Coleoptera: Scarabaeidae) do Parque Olhos D’Água. - Univ. Ci. Saúde 5: 1-13.

Nunes R.V., Frizzas M.R. \& VAz-De-Mello F.Z. 2012: Scarabaeinae (Coleoptera: Scarabaeidae) of a rupestrian field at Cafuringa, Distrito Federal, Brazil: commented list of species. - Biota Neotrop. 12: 125-129.

OliverRa P.E.A.M. 2008: Fenologia e biologia reprodutiva das espécies de Cerrado. In Sano S.M., Almeida S.P. \& Ribeiro J.F. (eds): Cerrado: Ecologia e Flora. Embrapa Cerrados \& Embrapa Informação Tecnológica, Brasília, pp. 273-290.

Oliveira C.M. \& Frizzas M.R. 2013: Field biology of the beetle Aegopsis bolboceridus in Brazil with a list of host plant. - J. Insect Sci. 13: 48, 15 pp.

Oliveira C.M. \& Mendonça J.S.F. 2011: Técnicas de coleta de Scarabaeoidea (Insecta: Coleoptera): Dispositivo antipilhagem de iscas em armadilha de queda. Embrapa Cerrados, Planaltina, Brazil, 4 pp.

Peacock L., Worner S. \& Sedcole R. 2006: Climate variables and their role in site discrimination of invasive insect species distributions. - Environ. Entomol. 35: 958-963.

Puker A., Correa C.M. \& Korasaki V. 2014: Deltochilini and Phanaeini dung beetles (Coleoptera: Scarabaeidae: Scarabaeinae) in introduced and native ecosystems of Brazil. $-J$. Nat. Hist. 48: 2105-2116.
R Development Core Team 2019: R: A Language and Environment for Statistical Computing. R Foundation for Statistical Computing, Vienna, URL: https://wwwr-projectorg.

RadtKe M.G., Carlton C.E. \& Williamson G.B. 2008: A dung beetle assemblage in an urban park in Lousiana. - Southeast. Nat. 7: 101-110.

RamíreZ-Restrepo L. \& HalfFter G. 2016: Copro-necrophagous beetles (Coleoptera: Scarabaeinae) in urban areas: a global review. - Urban Ecosyst. 19: 1179-1195.

Raupp M.J., Shrewsbury P.M. \& Herms D.A. 2010: Ecology of herbivorous arthropods in urban landscapes. - Annu. Rev. Entomol. 55: 19-38.

Rocha M.V.C. 2016: Diversidade de besouros rola-bosta (Coleoptera: Scarabaeidae: Scarabaeinae) em duas unidades de conservação do Cerrado do Brasil Central. MSc thesis, Universidade de Brasília, Brasília, ix +38 pp.

Sable M.G. \& Rana D.K. 2016: Impact of global warming on insect behavior - a review. - Agric. Rev. 37: 81-84.

SÁnchez-BAyo F. \& WyckhuYs K.A.G. 2019: Worldwide decline of the entomofauna: A review of its drivers. - Biol. Conserv. 232: 8-27.

SANCHEZ-PIÑERo N. 1997: Analysis of spatial and seasonal variability of carrion beetle (Coleoptera) assemblages in two arid zones of Spain. - Environ. Entomol. 26: 805-814.

Silva F.A.M., Assad E.D. \& Evangelista B.A. 2008: Caracterização climática do bioma Cerrado. In Sano S.M., Almeida S.P. \& Ribeiro F.E. (eds): Cerrado: Ecologia e Flora. Embrapa Informação Tecnológica, Brasília, pp. 69-88.

Silva R.J., Diniz S. \& VAZ-DE-Mello F.Z. 2010: Heterogeneidade do habitat, riqueza e estrutura da assembléia de besouros rolabostas (Scarabaeidae: Scarabaeinae) em áreas de cerrado na Chapada dos Parecis, MT. — Neotrop. Entomol. 39: 934-940.

Silva N.A.P., Frizzas M.R. \& Oliveira C.M. 2011: Seasonality in insect abundance in the Cerrado of Goiás state Brazil. - Rev. Brasil. Entomol. 55: 79-87.

Soanes K., Sievers M., Chee Y.E., Williams N.S., Bhardwaj M., Marshall A.J. \& Parris K.M. 2019: Correcting common misconceptions to inspire conservation action in urban environments. - Conserv. Biol. 33: 300-306.

SPECTOR S. 2006: Scarabaeine dung beetle (Coleoptera: Scarabaeidae: Scarabaeinae): an invertebrate focal taxon for biodiversity research and conservation. - Coleopts. Bull. 5: 71-83.

VAZ-DE-Mello F.Z. 2018: Scarabaeidae in catálogo taxonômico da fauna do Brasil. PNUD. URL: http://fauna.jbrj.gov.br/ fauna/faunadobrasil/127498.

VAZ-DE-Mello F.Z. \& GÉnIER F. 2009: Notes on the behavior of Dendropaemon Perty and Tetramereia Klages (Scarabaeidae: Scarabaeinae: Phanaeini). — Coleopts. Bull. 63: 364-366.

Venugopal K.S., Thomas S.K. \& Flemming A.T. 2012: Diversity and community structure of dung beetles (Coleoptera: Scarabaeinae) associated with semi-urban fragmented agricultural land in the Malabar coast in southern India. - J. Threat. Taxa 4: $2685-2692$.

Wintle B.A., Kujala H., Whitehead A., Cameron A., Veloz S., Kukkala A., Moilanen A., Gordon A., Lentini P.E., CadenHEAD N.C.R. \& BEKESSY S.A. 2019: Global synthesis of conservation studies reveals the importance of small habitat patches for biodiversity. — Proc. Natn. Acad. Sci. 116: 909-914.

YAHNER R.H. 1988: Changes in wildlife communities near edges. - Conserv. Biol. 2: 333-339.

Received November 18, 2019; revised and accepted May 18, 2020 Published online June 2, 2020 